Volume 15(1), 5-20

\title{
The Survival of Aboriginal Australians through the Harshest Time in Human History: Community-Strength
}

\author{
James A. Charles, Deakin University \\ Lewis O'Brien, Flinders University
}

Aboriginal People have inhabited the Australian continent before time began, but archaeologists and anthropologists state there is evidence for approximately 51,000 to 71,000 years of continual habitation. During this time, the Australian continent has experienced many environmental and climatic changes, which have contributed to mass animal extinction. The skeletal remains of Aboriginal Australians were examined for evidence, which may be indicative of fast running which would assist survival. The skull and mandible bones of the Kaurna People were examined for signs evolutional traits related to survival. Aboriginal culture, knowledge of medical treatment and traditional medicines were also investigated. Oral storytelling of factual events, passed down unchanged for millennia, contributed to survival. The Kaurna People exhibited evolutionary facial features that would have assisted survival. Kaurna People had excellent knowledge of medicine and the capacity to heal their community members. The process of mobility and relocation may have embedded the need to be mobile in some Aboriginal Australian cultures, and why many Aboriginal tribes did not invest too much time and resources in building permanent structures and dwellings. Navigating these extremely harsh, rapidly changing conditions is an incredible story of survival of Aboriginal Australians. The findings of this investigation suggest that Aboriginal Australians' survival methods were complex and multi-faceted. Although this paper could not examine every survival method, perhaps Aboriginal Peoples' knowledge of flora and fauna, (for nourishment and medicine) living in clans, and avoiding mass cohabitation was paramount to our survival.

Keywords: Aboriginal, Australia, survival, history, community-strength

\section{Disclaimer}

In some instances, in this paper the term 'Aboriginal' will be used. This will occur when the author is specifically referring to Aboriginal Australians.

\section{Warning}

Aboriginal and Torres Strait Islander Peoples: This paper has images of bones from deceased Aboriginal (Kaurna) People; however, it should be noted the images are copies of pictures, and not the original photographs.

\section{Acknowledgements}

I would like to acknowledge several Aboriginal communities and their representatives below for their support and contribution to this paper. The Awabakal, Worimi, Kaurna, Biripi, Darug, Paakantji, Ngiyampaa and the Mutthi Aboriginal communities. 


\section{Introduction}

Aboriginal People have a sacred connection to our land and we have inhabited the Australian continent before time began, and this has been expressed by Aboriginal Australians in our Dreaming stories, songlines, dance, and artworks (Brazil, 2000; Charles, 2015; Mountford, 1981; Taçon, 1991). Archaeologists and anthropologists estimated that Aboriginal People have inhabited the Australian continent for approximately 51,000 to 71,000 years (Malaspinas et al., 2016) during the Pleistocene period (Barker, Jones, McKay, \& McLeod, 2001). During this time, there has been many extended periods of stability and plentiful food supply. However, the Australian continent has experienced many environmental and climatic changes (i.e., fluctuating temperatures, ice ages, fluctuating $\mathrm{CO}_{2}$ levels, extremely high dust levels, high ice volume, high winds, large scale bush fires, glacial movement, low rain fall, extreme arid conditions, limited plant growth, evaporation of fresh water lakes, and dramatic sea level fluctuations. Please see Figure 1) All of these events have contributed to mass animal extinction (Bowler, 1976; Fielding, 2008; Johnson, 2006; Malaspinas et al., 2016; Monroe, 2011).

\section{Figure 1}

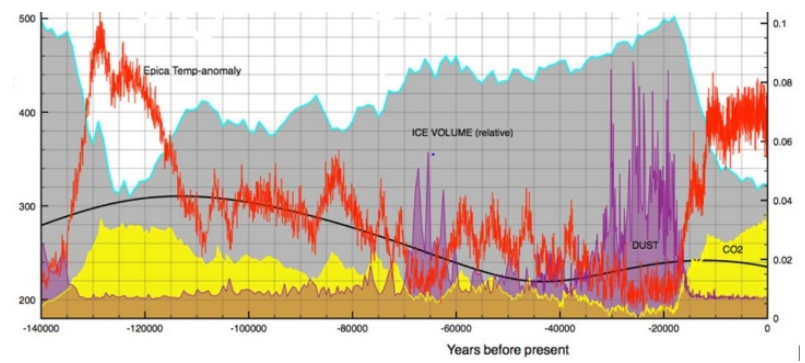

Note. Red graph (temperature), Purple graph (dust level), Grey graph (ice volume), Yellow graph (CO2 level) $\mathrm{x}$-axis is time in years and y-axis is volume (Best, 2016).

The very shape of the continent has changed dramatically with the drop and rise of sea levels, where approximately 8,00010,000 years ago the continent was much larger with sea levels $100-150 \mathrm{~m}$ lower than the current sea levels in 2018 (please see Figure 2) (Monroe, 2011; Voris, 2000). At this time of low sea levels, the Australian state of Tasmania to the south and the nation of Papua New Guinea to the north created land bridges to mainland Australia. The Great Barrier Reef on Australia's east coast was above sea level, the land mass at that time was much greater than today, and created an ancient super continent i.e., Sahul (Malaspinas et al., 2016).

\section{Figure 2}

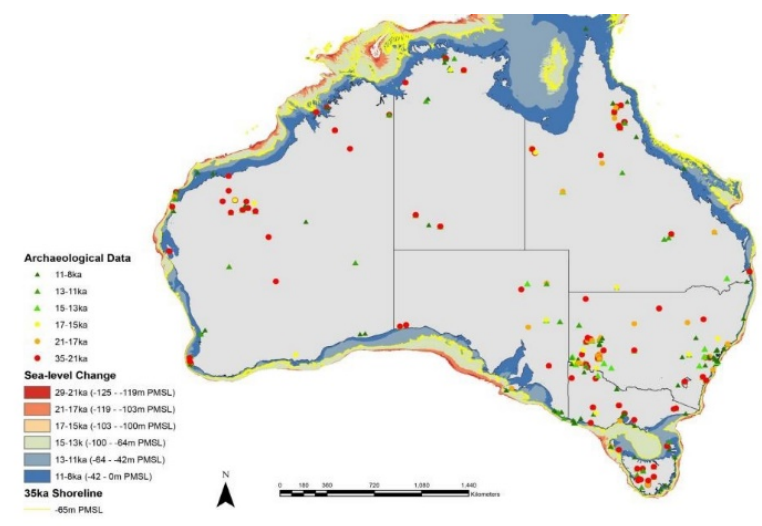

Note. Map of Australia showing sea level changes and archaeological sites for selected periods between 35,000 and 8,000 year ago (Ulm, 2016).

Surviving in Australia over the millennia, over some extended periods, would have been relatively easy with food sources and fresh water plentiful. However, over some extended periods it would have been incredibly difficult, where some of the environmental and climatic changes would 
have been catastrophic for many Aboriginal tribes and unimaginably difficult by today's relative mild environmental conditions. The incredible speed of climate change would have required great adaptability of our ancestors (Voris, 2000), and many would have found it extremely difficult to cope with these drastic and sudden changes (Monroe, 2011).

This paper focuses on the incredible survival story of Aboriginal Australians through a period from approximately 32,000 to 17,000 years ago which would have been difficult for all forms of life on the continent to survive (please see Figure 1). This paper will also examine Aboriginal Australian knowledge, Dreaming stories, and cultural practices to investigate links with modern scientific facts. During this time period (32,000 to 17,000 years ago) the temperature would have been approximately 10-20 degrees Celsius lower than today, likely linked to extremely low $\mathrm{CO}_{2}$ levels at that time. The depletion of plant life from low temperature, high winds, bush fires, and low rainfall and consumption of plants from large herbivores would have contributed to the extremely high dust levels and low visibility also seen at this time. This reduction of plant life may have contributed to mass extinction of large herbivores inhabiting Sahul at this time and the domino effect that would have also contributed to extinction of large carnivores and impacted on Aboriginal Peoples' food source (Johnson, 2006). One of the most challenging times to survive on Sahul was approximately 25,000 years ago at the last ice age (Williams, Ulm, Cook, Langley, \& Collard, 2013). When the continent became incredibly arid, $\mathrm{CO}_{2}$ levels were at a low point, plant life would have struggled to grow, temperature was at its lowest point for millennia, dust levels reached its peak, visibility was low and fresh water lakes emptied (Figure 1-3) (Williams et al., 2013).
Conditions were extremely harsh and it is thought that the population of Aboriginal Australians declined by approximately $60 \%$ (Williams et al., 2013). Although there were many extended difficult periods to survive on Sahul, it is this period approximately 25,000 years ago which would have required the knowledge passed down from our ancestors about environmental change, and adaptability, and it is a truly incredible feat of resilience by the Aboriginal People of Australia. These conditions were far harsher conditions than those experienced when Neanderthals became extinct 70,000 to 50,000 years ago (Shea, 2008), although there is some evidence Neanderthals survived up until approximately 28,000 years ago (Finlayson et al., 2006). This paper will investigate the incredible survival story of Aboriginal People, through some of the harshest conditions in human history, the link between scientific evidence, and the strength of Aboriginal cultural knowledge and oral history.

\section{Methods}

Scientific and Aboriginal evidence was collected for comparison. Footprints from Lake Mungo (Mungo National Park, NSW Australia) were examined to predict foot arch height and approximate the speed in which some Aboriginal men were running. The skeletal remains from Karraundo-ngga (Kaurna language for Hindmarsh area in Adelaide SA Australia) including the broken femur bone of a Kaurna (Aboriginal) man was examined for treatment and therapy. The skull and mandible bones were examined for signs of evolutional traits related to survival in tough environmental conditions. Aboriginal culture, and knowledge of medical treatment, therapies, and traditional medicines were investigated that may have contributed to survival. 


\section{Relationship}

The authors are Kaurna (Aboriginal) men from the Adelaide Plains in South Australia and have community, cultural, and ancestral connections to the Kaurna People examined in this paper. The Kaurna People are the traditional owners of the Adelaide Plains and we still maintain our cultural heritage, beliefs, and connection to our land and waterways. The authors also have relationships with many Aboriginal and Torres Strait Islander communities around Australia. Written approval from the Willandra Lakes Region World Heritage Area Technical and Scientific Advisory Committee and the Community Management Council (TSAC and CMC), representing the Paakantji, the Ngiyampaa, and the Mutthi Mutthi Aboriginal Peoples was provided to visit their country and inspect the 21,000-year-old fossil footprints. In addition, the first author was given access to data previously collected by these communities. 103 Kaurna People were removed in the 1950s from a gravesite in Karraundo-ngga and were housed in the South Australian museum archives. Approval was given from Uncle Lewis Yerloburka O'Brien (Kaurna Elder) and the South Australian Museum to inspect skeletal remains of the author's ancestors.

\section{Limitations}

This project examined skeletal remains of Aboriginal People for possible links to survival methods and techniques. The skeletal remains examined were also of relatively small number and the extent of generalizability of the characteristics of these bones to the greater Kaurna community is unknown. The scope of this research was restricted and not every aspect or survival method was investigated.

Nevertheless, the authors believe these findings make a valuable contribution to the current understanding of survival of
Aboriginal People through one of the toughest environmental conditions in human history.

\section{Results}

\section{Aboriginal Oral History}

Interestingly, Aboriginal Australians are sometimes undermined for not having written documented history, but it may have been oral story telling of factual events, passed down unchanged for millennia which contributed greatly to our survival. Many Aboriginal tribes have been practising survival education for millennia with Dreaming stories, songlines, dance, paintings, and carvings (Broome, 1982; Charles, 2015; Isaacs, 1980). Many Dreaming stories are about creation, but many are also about teaching and learning as some of this educating is designed to assist survival. Many Dreaming stories are often set in conflict between right and wrong, jealousy, arguments, and disagreements where listeners are able to learn from the mistakes made by animals, creators, and ancestors in these songlines, dance, stories, and paintings (Broome, 1982; Charles, 2015). Traditional lifestyles were able to be guided by Dreamtime stories, designed to keep people safe and well (e.g., eating the right foods and using medicines in the right amount, prepared in the right way, and at the right time of year (season), which is like modern day health promotion) (Broome, 1982; Charles, 2015; Isaacs, 1980). There are many Aboriginal oral Dreaming stories which record that sea levels were much lower than they are today (Barker et al., 2001; Campbell, 1967). This is of course is a true geological environmental fact about the Australian continent and it is incredible that this Aboriginal oral history has been shared down approximately 320 generations accurately for at least 8,000 years (Campbell, 1967). These historic stories 
were kept intact and unchanged, reflecting precisely geological facts of the Australian continent cooperated by many different Aboriginal tribes in the same geographical area (Barker et al., 2001). The ancestors of the Gunaikurnai People, the traditional owners of Gippsland area in Victoria, Australia, have Dreaming stories of their country extending further south which is now covered by the ocean today (Fison $\&$ Howitt, 1880; Fison \& Howitt, 1880). The Wurundjeri and "Wannadrung" (Note: name may have been misinterpreted by colonists, it may be Wadawurrung) tribes around what is currently Port Phillip Bay in Victoria, were reported as stating to the colonists that there was previously plenty of kangaroo and possum in the Port Phillip Bay, obviously referring to a time when the sea level was much lower (Barker, 1854). Similar Aboriginal Dreaming stories were told by nearby tribes of the Mornington Peninsula, the Bunurong People, stating the low lands (Port Phillip Bay) became flooded very quickly following a violent storm and the earth shaking (earthquake) (Rogers, 1966). The Ngarrindjeri tribe of South Australia also had oral history passed down generations, of being able to walk to Kangaroo Island, which is currently several kilometres of the coast of South Australia (Campbell, 1967) but the track to Kangaroo Island would have been above sea level and part of mainland Australia 8,000 - 10,000 years ago.

\section{Refuges for Survival}

There is research that suggests that surviving the very harsh conditions of the last ice age in Australia approximately 25,000 years ago was to seek refuge where there was still fresh drinkable water, cover, and plant life (Williams et al., 2013). It is believed that all Aboriginal and Torres Strait Islander people of Australia at that time migrated to 11 distinct refugia (please see
Figure 3) and abandoned approximately $80 \%$ of the Australian landscape temporarily because it was uninhabitable (Williams et al., 2013). Although this theory seems plausible, it should be noted that this study could not investigate every part of the continent or other possible populations and refugia. Interestingly, based on Williams et al 2013 theory, the main population centres are several hundred kilometres inland or possibly even thousands of kilometres inland with sea levels being much lower at that time, which seems counterintuitive to survival considering the sources of sustainability the ocean could provide, so perhaps it was a fear of potential fast rising oceans that led to inland settlement.

\section{Figure 3}

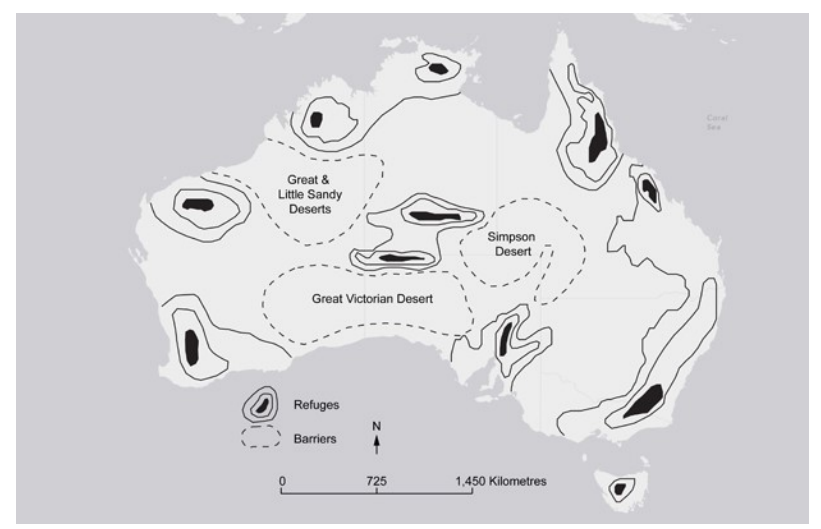

Note. Refuges of survival during the last ice age in Australia (Williams et al., 2013).

\section{Athleticism and Survival}

Aboriginal Australians have demonstrated great intelligence and knowledge of our environment, which have developed over the millennia (Watkins et al., 2006; Webb, Cupper, \& Robins, 2006).

Some of this ability to adapt to environmental conditions has been an evolutionary process (Webb, 2007) as a knowledge and understanding of flora and fauna would have been fundamental to survival (Westaway, 2010). Physical ability would have been paramount to survival and 
integral to many Aboriginal cultures (Robert, 1878; Taplin, 1879; Watkins et al., 2006). Successful hunting would have required great intellect, knowledge of the fauna and the environment, but obviously athleticism was essential for hunting (Grubb, 2011). Sahul had megafauna e.g., giant kangaroo and emu 3 metres tall, and giant wombat weighing over 1tonne. Although approximately $85 \%$ of megafauna became extinct about 50,000 years ago and most disappeared 25,000 years ago, around the time of the last ice age (Miller et al., 1999; Roberts et al., 2001; Wroe \& Field, 2006) there is evidence of giant kangaroo and emu surviving 21,000 years ago in Southern Sahul, with paw prints found at Lake Mungo in the Willandra Lakes World Heritage area of NSW, Australia (Johnston, 2014).

\section{Skeletal Anatomical Features}

The Kaurna People of the Adelaide Plains area in South Australia exhibit very large nasal cavities (please see Figure 4) which may have assisted with extremely harsh ice age temperatures via warming very cold air before entering the sinus passages, throat, and lungs. These large nostrils would have also limited entry of pathogens like bacteria, fungi, and viruses (Barberán et al., 2015; Dutkiewicz, 1978; Kellogg \& Griffin, 2006) preventing infection(s) that may have been life threatening, as these large nostrils and hair would have captured pathogens (Gonzalez-Martin, Teigell-Perez, Lyles, Valladares, \& Griffin, 2013). The Kaurna People also exhibited a very broad and pronounced brow and large eye sockets useful for protecting the eyes in extremely dusty, windy, and smoky (from bush fires) conditions experienced 15,000 to 35,000 years ago, helping with visibility and limiting eye infection(s) carried in dust (Vismer, Marasas, Rheeder, \& Joubert, 2002).

\section{Figure 4}

Skull of 60-year-old Kaurna Man

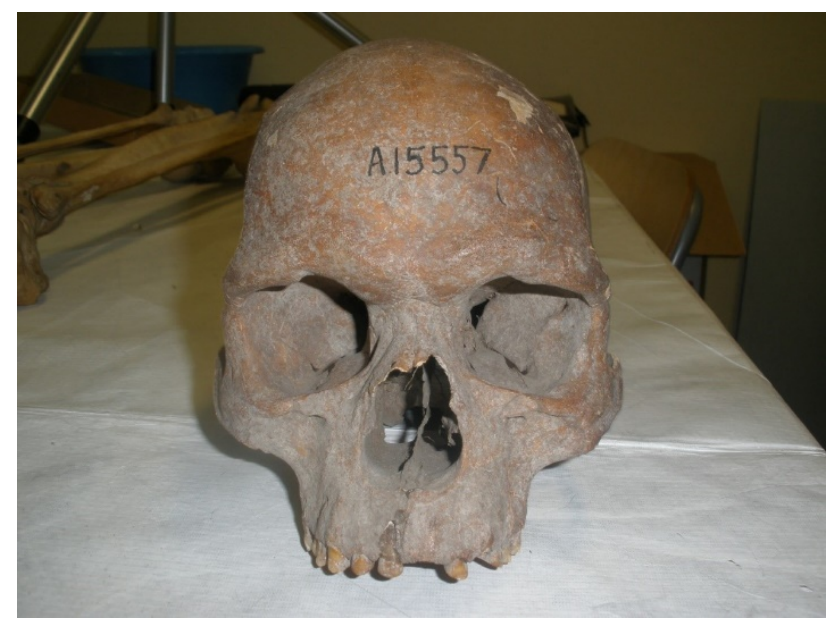

The skull and accompanying mandible (please see Figure 5) of an approximately 60-year-old Kaurna man show the teeth to be in excellent condition with no decay, which was the case with all 103 skeletal remains. This is an indication that the Kaurna People, despite the difficult environmental conditions, managed to maintain a healthy, balanced diet, which included adequate calcium levels, which is known to improve bone (Fonseca \& Ward, 2004) and strength (Kornegay \& Thomas, 1981). These skeletal facial features and bone health would likely have contributed to the Kaurna Peoples survival in harsh environmental conditions. 
Figure 5

Mandible of 60-year-old Kaurna Man

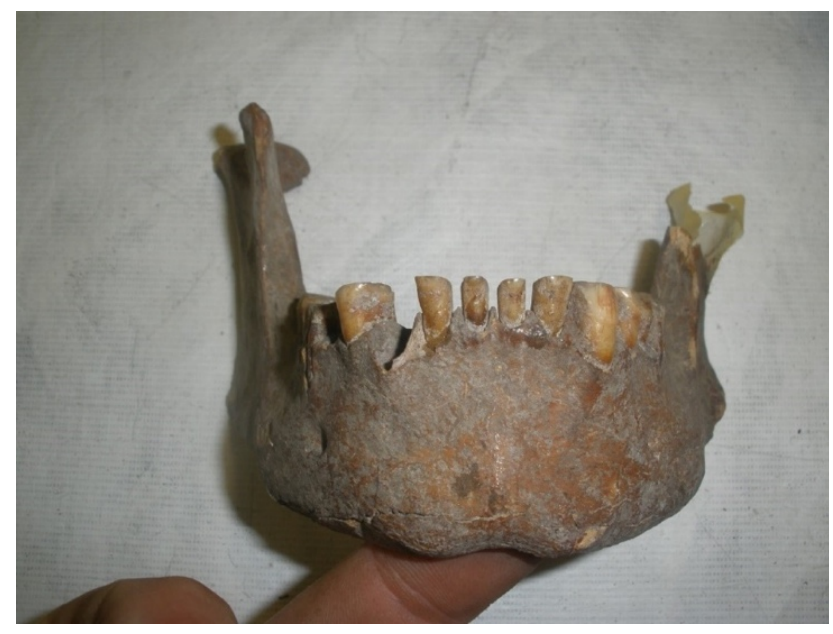

Culture, Medicine and Treatments

Figure 6 contains the right and left femur of a Kaurna man with the right femur having a completely healed compound fracture at the neck and shaft of the femur. These types of injuries are very difficult to heal, even for modern medical professionals (Davidovitch, Jordan, Egol, \& Vrahas, 2010) and usually require fixation surgery (Christie, Court-Brown, Kinninmonth, \& Howie, 1988; Mackenzie, 1971). Even with the best modern surgical practices and medicines, the rate of non-union and necrosis with these compound fractures is approximately $50 \%$ (Davidovitch et al., 2010). The fact that this Kaurna man had this injury completely healed is strong evidence the Kaurna People were in good health, had excellent knowledge of medicine and therapies, with the capacity to heal our community members, including from serious medical emergencies. The sizable calcification around the fracture suggests this 60 year old man lived for at least 5 years after the incident which caused the fracture (likely to be a fall from a great height) (Bourque, Gross, \& HAll, 2004).

\section{Figure 6}

Compound Fracture of Right Neck and Shaft
of Femur

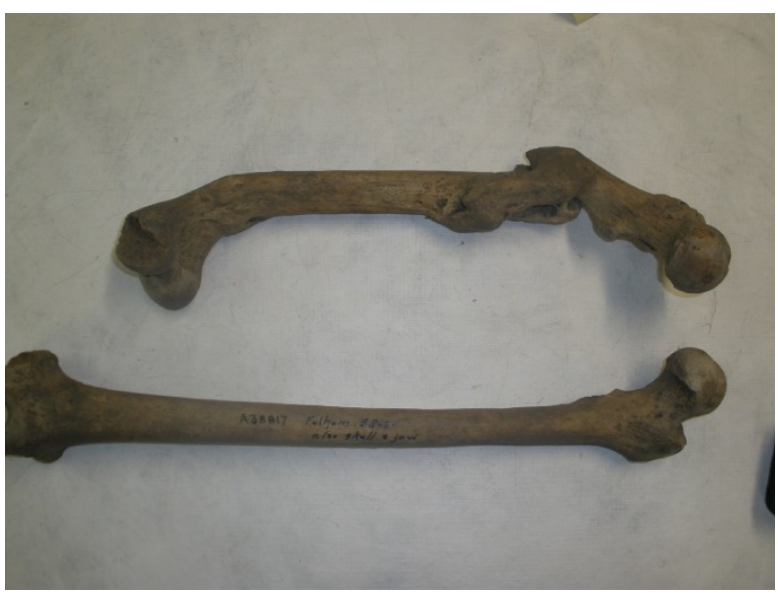

The fall from a great height may have been while climbing a tree, perhaps for hunting (possum) or finding a scoping viewpoint, which the Kaurna and other tribes were known to do regularly (Lumholtz, 1889; Watkins et al., 2006). This suggests that at least part of the Kaurna survival strategy and perhaps part of our success was regular tree climbing. However, the most important evidence for the Kaurna Peoples ability to survive is the fact that this 60year-old man survived such a severe compound fracture of the neck and shaft of the femur bone. This would have been a life ending injury in many cases for people from other cultures without knowledge of treatment and therapies, certainly in the harsh environmental conditions of the time. For the Kaurna man who was in his 60s (an Elder), to survive such a horrific injury would have taken an extreme level of support from the Kaurna community i.e., "community-strength", certainly from many members working together. This may be the most important aspect of survival in these harsh conditions -the culture of "community-strength" within tribes- and perhaps one of the earliest examples of 
"community-care" which many Aboriginal tribes are known for today (Berry et al., 2010; Rowley et al., 2000). This Kaurna man would have been in extreme pain, for a very long period of time, and would have been immobile for many months and would have required constant support (Fox et al., 2000). The recovery and rehabilitation from such an injury would have required knowledge of treatment, therapies, and medicines for serious injury. Indeed, the Kaurna People did have knowledge of medicine to reduce pain, a shrub (pituri plant) that produces an alkaloid which contains nicotine (Langley \& Dickinson, 1890). The Kaurna people administered pituri in high doses to reduce pain (Langley \& Dickinson, 1890; Watkins et al., 2006; Watson, 1983). Pituri would have been an important medicine (narcotic) (Johnston \& Cleland, 1933) with a compound fracture, which would have been incredibly painful.

The possibility to die from blood loss would have been possible with an injury of this type. However, if the person did not bleed out, the possibility of contracting an infection would have been the greatest risk of a life-ending event. The Kaurna People had knowledge of medicine to prevent and/or treat infection and this would have been paramount to this man's survival. Honey has been used by Aboriginal Australians for thousands of years to treat wounds and a variety of skin complaints, including the Kaurna People (Boorn et al., 2010). Although it had been dismissed by many western medical professionals for many years, it is now commercially available for many purposes (e.g., MediHoney). MediHoney has been shown to be effective for a variety of wounds including those colonised or infected with multi-resistant staphylococcus aureus (MRSA) (Blaser, Santos, Bode, Vetter, \& Simon, 2007). Other studies showed MediHoney to be effective against 58 strains of staphylococcus aureus and 20 strains of pseudomonas, and that honey dressing were able to produce sterile wounds in 3-10 days (Molan, 1999). It would have been likely that this man's wound would have been treated with Honey as an antibacterial. Tea Tree oil has also been used by many Aboriginal Australian tribes as a disinfectant against bacteria, fungi, and many other skin problems (Carson, Hammer, \& Riley, 2006; Tong, Altman, \& Barnetson, 1992), including an effective agent against MRSA (Caelli, Porteous, Carson, Heller, \& Riley, 2000). This Aboriginal Australian traditional medicine was also ignored by western practitioners but is now commercially available and widely used. The knowledge of the properties of Tea Tree Oil, by the Kaurna and other tribes and its abundance, means it is very likely it would have been used to treat this Kaurna man's wound. The Kaurna People would have had this man lay in a bed of eucalyptus leaves and applied some leaves directly to the wound site as an antibiotic, as the leaves dry they will also absorbed fluid and cushion the wound site. There are many other traditional Aboriginal medicines and treatments used for wounds, pain, and injury that the Kaurna People would have likely used (Watkins et al., 2006). There was traditional knowledge of medicines for inflammation that were widely available to the Kaurna People and useful in the treatment of this man (Devanesen, 2000). Many modern surgical techniques involve surgical screws and internal braces to the bone for such a fracture this Kaurna man experienced (Christie et al., 1988). This injury and accompanying wound would have needed bracing of some form for it to heal and reduce pain and allow union of the bone (Herbert \& Fisher, 1984) and the Kaurna People did have exceptional knowledge of human anatomy (Watkins et al., 2006). The amount of sizable calcification tells us that this man did in fact get back up and was 
weight bearing for several years, which is an incredible outcome and a credit to the Kaurna Peoples knowledge and communitystrength.

\section{Discussion}

\section{Aboriginal Oral History}

The ancient historical geological knowledge held by these Aboriginal Peoples, of their country would have assisted their survival. Knowing the potential for massive sudden geological shift and potential rise and fall of sea levels and spread of disease would have likely influenced their decisions about where to live. Whether or not to have permanent settlement at one site and committing great time and resources in settling permanently on the coast, or low-lying land. It is welldocumented that the Kaurna People of Adelaide Plains in South Australia would only have temporary dwellings and shift from near the coast to the shelter of the hills seasonally and main settlements that were several kilometres inland. The Kaurna People also spread out and lived in family groups and clans (Watkins et al., 2006). This regular rotation of dwelling was about flora and fauna regeneration and disease prevention i.e., leaving human and animal waste behind to decompose. Interestingly the permanent settlement at one single site, and rapid gathering of the masses in European cities led to the death of millions from disease (Scott, Duncan, \& Duncan, 1996). Perhaps the culture of nomadic rotation of sites and dwellings of many Aboriginal Australian tribes, living separately of family groups and clans, but supporting the entire tribe was based on knowledge that was passed down from our ancestors to look after mother earth, allow regeneration, and preventing disease spread. This was also based on preservation of time and resources that could be lost with the fluctuation of sea level and climate change. This Aboriginal knowledge and culture of community-strength would have contributed to the survival of Aboriginal Australians.

\section{Refuges for Survival}

The mobility of these Aboriginal People over such long distances to reach refugia, through such incredibly difficult environmental conditions, is staggering. This mobility truly would have been a "survival of the fittest" and certainly many sacrifices would have had to been made to reach these destinations. One can only image the desperate journey to arrive at these refugia. This is a clear demonstration of the community-strength, adaptability, and resilience of the Aboriginal People of Australia. This process of mobility and relocation may have embedded the need to be mobile in some Aboriginal Australian cultures, and why many Aboriginal tribes did not invest too much time and resources in building permanent structures and dwellings and resisted cohabitation in one large group (Watkins et al., 2006).

\section{Athleticism and Survival}

To successfully hunt these very large and fast moving pre-historic animals it would have taken great skill, knowledge and athleticism by the Aboriginal People of this time (Charles, 2017, 2018). Modern day wombats have a top speed of $40 \mathrm{~km} / \mathrm{hr}$, kangaroos have a top speed of $70 \mathrm{~km} / \mathrm{hr}$, and emu are one the fastest land birds on the planet at 50km/hr (Bennett, 1987; Garland, 1983; Heglund, Fedak, Taylor, \& Cavagna, 1982). There is no evidence for the running speed of giant wombat, kangaroo and emu but because of their size, and similar ratio, they may have been even faster than their modern relatives. However, regardless of their speed, their size and strength alone would have made hunting these giant animals much harder and would have likely 
take great athleticism and teamwork from many members of the community. Despite their possible great speed and known size of these pre-historic animals, several studies reported that Aboriginal Australians were very successful hunters of megafauna (Miller et al., 1999; Roberts et al., 2001; Wroe \& Field, 2006). This successful hunting style, relying on communitystrength would have contributed to the survival of Aboriginal Australians.

In conjunction with the required knowledge of their environment, flora and fauna, Aboriginal Peoples have evolved foot structure and function that is conducive to athleticism, which would have improved hunting success and assisted their survival. The first author has recently demonstrated some aspects of foot and ankle morphology and function that are highly prevalent in modern day Aboriginal Peoples, including a high arched foot type and reduced ankle joint range of dorsiflexion (ankle equinus) (Charles, 2015, 2017). The author found ankle equinus was highly prevalent especially in males and most commonly affected the gastrocnemius muscle (Charles, 2015, 2017). This previous research indicated that both the foot arch type and the range of ankle joint dorsiflexion affected plantar pressures, with a tendency to increase the duration and degree of forefoot loading (Charles, 2017, 2018), and this is thought to have contributed to the athleticism of Aboriginal Australians. Although due to the cross-sectional nature of these studies, the findings are not generalizable to the total Aboriginal and Torres Strait Islander population.

Although not generalizable, it is possible both an ankle equinus and a high arch foot type are an evolutionary biomechanical development to increase running speed and thereby improve hunting ability and survival (Nigg, Cole, \& Nachbauer, 1993). The great running speed of ancient Aboriginal Australians has been documented at Lake Mungo in the Willandra Lakes World Heritage area of NSW, Australia (Johnston, 2014). Some of the men running at Lake Mungo, are taking approximately 25 steps to travel an approximately 50 metres or if extrapolated 50 steps to travel 100m (Charles, 2018). This stride pattern is similar to some of the modern world's high performance athletes (Hanon \& Gajer, 2009). If the Aboriginal men at Lake Mungo are taking 50 steps to travel $100 \mathrm{~m}$ this would be an estimated sub 11 seconds to run 100m (Faccioni, 2016). Using a pace calculator (Net, 2016) this is an estimated top speed of $35 \mathrm{~km} / \mathrm{h}$. It must also be considered that these men were running barefoot, in soft ground (mud), and likely carrying a weapon(s) and/or other item(s) (Charles, 2018). However, these calculations of the ancient Aboriginal men running $100 \mathrm{~m}$, is an estimate based on an extrapolation of a $50 \mathrm{~m}$ run, and there is no way of knowing if these men could have maintained this stride pattern. This athleticism would have been a key component of survival of Aboriginal Australians. Especially having to travel vast distances to reach refuges and escape unviable land and unliveable environmental conditions (Williams et al., 2013). However, athleticism and the ability run fast would have only been part of the survival though the last ice age.

\section{Culture, Medicine and Treatments} It could be argued that the Kaurna Peoples knowledge and use of traditional medicines, therapies, and treatments would have certainly contributed greatly to our survival through difficult environmental conditions. 


\section{Conclusion}

The Australian continent has experienced many environmental and climatic changes over the millennia that would have been an extremely challenging for the Aboriginal People of Australia. However, a period of two thousand years, approximately 24,000 to 26,000 years ago which would have been especially tough to survive through. Navigating these extremely harsh, rapidly changing conditions is an incredible story of survival of Aboriginal Australians. The findings of this investigation suggest that Aboriginal Australians survival methods were complex and multi-faceted. There is evidence of an evolutionary component to survival, including facial features and biomechanics that would have contributed to survival. Aboriginal Australians have demonstrated incredible endurance and fitness for mobility and a strong "will" to survive. However, perhaps our community mindedness and community-strength is a very powerful tool of resilience and resistance. Our culture, knowledge, and understanding of flora and fauna for nourishment and medicine and other medical treatments was paramount to the survival of Aboriginal Australians. The benefits of living in family groups or clans and avoiding mass cohabitation, knowledge was passed down from ancestors and was a key aspect of preventing the spread of disease, seen in other continents like Europe. The potential for rapid change to earth's environment and its impact on all inhabitants experienced by Aboriginal Australians is perhaps a lesson for modern Aboriginal and non-Aboriginal people of our earth.

\section{References}

Barberán, A., Ladau, J., Leff, J. W., Pollard, K. S., Menninger, H. L., Dunn, R. R., \& Fierer, N. (2015). Continental-scale distributions of dust-associated bacteria and fungi. Proceedings of the National Academy of Sciences, 201420815. https://doi.org/10.1073/pnas.142081511 2

Barker, J. E., Jones, F. F., McKay, H. F., \& McLeod, P. (2001). Gadi mirrabooka : Australian Aboriginal tales from the dreaming (H. F. McKay Ed.). Englewood, Colo: Libraries Unlimited. Barker, W. (1854). Report from the Select Committee of the Legislative Council on the Claims for the Discovery of Gold in Victoria: together with the proceedings of Committee, minutes of evidence and appendix. Melbourne: John Ferres, Government Printer.

Bennett, M. (1987). Fast locomotion of some kangaroos. Journal of Zoology, 212(3), 457-464. https://doi.org/10.1111/j.1469-

7998.1987.tb02916.x

Berry, H. L., Butler, J. R., Burgess, C. P., King, U. G., Tsey, K., Cadet-James, Y. L., . . Raphael, B. (2010). Mind, body, spirit: co-benefits for mental health from climate change adaptation and caring for country in remote Aboriginal Australian communities. New South Wales Public Health Bulletin, 21(6), 139-145. https://doi.org/10.1071/NB10030

Best, C. (2016, October 08). When is the next Ice Age due? Retrieved from http://clivebest.com/blog/?p=7344

Blaser, G., Santos, K., Bode, U., Vetter, H., \& Simon, A. (2007). Effect of medical honey on wounds colonised or infected with MRSA. Journal of wound care, 16(8), 325-328. https://doi.org/10.12968/jowc.2007.16.8 .27851

Boorn, K., Khor, Y. Y., Sweetman, E., Tan, F., Heard, T., \& Hammer, K. (2010). Antimicrobial activity of honey from the stingless bee Trigona carbonaria determined by agar diffusion, agar 
dilution, broth microdilution and timekill methodology. Journal of applied microbiology, 108(5), 1534-1543. https://doi.org/10.1111/j.13652672.2009.04552.x

Bourque, W. T., Gross, M., \& HAll, B. K. (2004). Expression of four growth factors during fracture repair. International Journal of Developmental Biology, 37(4), 573-579.

Bowler, J. M. (1976). Aridity in Australia: Age, origins and expression in aeolian landforms and sediments. Earth-Science Reviews, 12(2), 279-310. https://doi.org/10.1016/00128252(76)90008-8

Brazil, J. (2000). Dreamtime superstore: Encountering Australian aboriginal beliefs. Third Text, 14(50), 61-72. https://doi.org/10.1080/0952882000857 6837

Broome, R. (1982). Aboriginal Australians: Allen \& Unwin Sydney.

Caelli, M., Porteous, J., Carson, C., Heller, R., \& Riley, T. (2000). Tea tree oil as an alternative topical decolonization agent for methicillin-resistant Staphylococcus aureus. Journal of Hospital Infection, 46(3), 236-237.

https://doi.org/10.1016/S01956701(00)90830-2

Campbell, A. H. (1967). Aboriginal traditions and the prehistory of Australia. The Australian Journal of Anthropology, 6(10), 476. https://doi.org/10.1111/j.18359310.1967.tb01351.x

Carson, C., Hammer, K., \& Riley, T. (2006). Melaleuca alternifolia (tea tree) oil: a review of antimicrobial and other medicinal properties. Clinical microbiology reviews, 19(1), 50-62. https://doi.org/10.1128/CMR.19.1.5062.2006

Charles, J. (2015). An evaluation and comprehensive guide to successful aboriginal health promotion. Austr Indigen Health Bull, 16(1), 1-8.

Retrieved from http://healthbulletin.org.au/articles/anevaluation-and-comprehensive-guideto-successful-aboriginal-healthpromotion

Charles, J. (2017). An investigation into ankle joint dorsiflexion, musculoskeletal injury, arch height, foot pressure and diabetes in association with poor foot health outcomes in an Aboriginal population. (Research Doctorate Doctor of Philosophy (PhD) By Publication), University of Newcastle, Newcastle. Retrieved from http://hdl.handle.net/1959.13/1353477 (uon:31102)

Charles, J. (2018). Musculoskeletal injury and the correlation with foot plantar pressure in an Australian Aboriginal population. Australian Indigenous Health Bulletin, 18(1). Retrieved from http://healthbulletin.org.au/articles/musc uloskeletal-injury-and-the-correlationwith-foot-plantar-pressure-in-anaustralian-aboriginal-population

Christie, J., Court-Brown, C., Kinninmonth, A., \& Howie, C. (1988). Intramedullary locking nails in the management of femoral shaft fractures. The Journal of bone and joint surgery. British volume, 70(2), 206-210. https://doi.org/10.1302/0301620X.70B2.3346289

Davidovitch, R. I., Jordan, C. J., Egol, K. A., \& Vrahas, M. S. (2010). Challenges in the treatment of femoral neck fractures in the nonelderly adult. Journal of Trauma and Acute Care Surgery, 68(1), 236-242. https://doi.org/10.1097/TA.0b013e3181 c428ce

Devanesen, D. D. (2000). Traditional Aboriginal medicine practice in the Northern Territory. 
Dutkiewicz, J. (1978). Exposure to dustborne bacteria in agriculture.

Environmental studies. Archives of Environmental Health: An International Journal, 33(5), 250-259. https://doi.org/10.1080/00039896.1978. 10667344

Faccioni, A. (2016). Complete Sprinting Technique. Retrieved from http://www .adriansprints.com/2011/03/c omplete-sprinting-techniquecharlie.html

Fielding, C. R., Frank, T. D., Birgenheier, L. P., Rygel, M. C., Jones, A. T., \& Roberts, J. (2008). Stratigraphic record and facies associations of the late Paleozoic ice age in eastern Australia (New South Wales and Queensland). https://doi.org/10.1130/2008.2441(03)

Finlayson, C., Giles Pacheco, F., RodríguezVidal, J., Fa, D. A., María Gutierrez López, J., Santiago Pérez, A., . . . Sakamoto, T. (2006). Late survival of Neanderthals at the southernmost extreme of Europe. Nature, 443, 850. https://doi.org/10.1038/nature05195

Fison, L., \& Howitt, A. (1880). Kamilaroi andKurnai. In: George Roberston, Melbourne, Sydney, Adelaide and Brisbane.

Fison, L., \& Howitt, A. W. (1880). Kamilaroi and Kurnai: Group Marriage and Relationship, and Marriage by Elopement... Also the Kurnai Tribe: Their Customs in Peace and War: George Robertson.

Fonseca, D., \& Ward, W. E. (2004). Daidzein together with high calcium preserve bone mass and biomechanical strength at multiple sites in ovariectomized mice. Bone, 35(2), 489497. https://doi.org/10.1016/j.bone.2004.03.0 31

Fox, K., Magaziner, J., Hawkes, W., YuYahiro, J., Hebel, J., Zimmerman, S., . .
. Michael, R. (2000). Loss of bone density and lean body mass after hip fracture. Osteoporosis International, 11(1), 31-35. https://doi.org/10.1007/s001980050003

Garland, T. (1983). The relation between maximal running speed and body mass in terrestrial mammals. Journal of Zoology, 199(2), 157-170. https://doi.org/10.1111/j.14697998.1983.tb02087.x

Gonzalez-Martin, C., Teigell-Perez, N., Lyles, M., Valladares, B., \& Griffin, D. W. (2013). Epifluorescent direct counts of bacteria and viruses from topsoil of various desert dust storm regions. Research in microbiology, 164(1), 1721. https://doi.org/10.1016/j.resmic.2012.08 .009

Grubb, P. L. (2011). Persistence Hunting and the Evolution of Human Endurance Running. Graduate Student Journal of Anthropology, 33.

Hanon, C., \& Gajer, B. (2009). Velocity and Stride Parameters of World-Class 400Meter Athletes Compared With Less Experienced Runners. The Journal of Strength \& Conditioning Research, 23(2), 524-531. https://doi.org/10.1519/JSC.0b013e318 $194 \mathrm{e} 071$

Heglund, N. C., Fedak, M., Taylor, C., \& Cavagna, G. (1982). Energetics and mechanics of terrestrial locomotion. IV. Total mechanical energy changes as a function of speed and body size in birds and mammals. Journal of Experimental Biology, 97(1), 57-66. https://doi.org/10.1146/annurev.ph.44.0 30182.000525

Herbert, T. J., \& Fisher, W. E. (1984). Management of the fractured scaphoid using a new bone screw. The Journal of bone and joint surgery. British volume, 66(1), 114-123. 
https://doi.org/10.1302/0301-

620X.66B1.6693468

Isaacs, J. (1980). Australian dreaming: 40,000 years of Aboriginal history:

Lansdowne Press Sydney.

Johnson, C. (2006). Australia's Mammal Extinctions : A 50,000 year history. Port Melbourne: Cambridge University Press.

Johnston, H. (2014). The Willandra Lakes Region World Heritage Area, New South Wales, Australia: Land Use Planning and Management of Aboriginal and Archaeological Heritage. In Archaeological Dimension of World Heritage (pp. 39-55):

Springer. https://doi.org/10.1007/978-14939-0283-5_4

Johnston, T. H., \& Cleland, J. B. (1933).

The history of the Aboriginal narcotic, pituri. Oceania, 4(2), 201-223. https://doi.org/10.1002/j.18344461.1933.tb00101.x

Kellogg, C. A., \& Griffin, D. W. (2006). Aerobiology and the global transport of desert dust. Trends in ecology \& evolution, 21(11), 638-644. https://doi.org/10.1016/j.tree.2006.07.00 4

Kornegay, E., \& Thomas, H. (1981).

Phosphorus in Swine. II. Influence of Dietary Calcium and Phosphorus Levels and Growth Rate on Serum Minerals, Soundness Scores and Bone Development in Barrows, Gilts and Boars 1. Journal of animal science, 52(5), 1049-1059. https://doi.org/10.2527/jas1981.525104 9x

Langley, J. N., \& Dickinson, W. L. (1890). Pituri and nicotin. The Journal of physiology, 11(4-5), 265-306. https://doi.org/10.1113/jphysiol.1890.sp 000332

Lumholtz, C. (1889). Among cannibals: an account of four years' travels in
Australia and of camp life with the Aborigines of Queensland: London: J. Murray.

Mackenzie, D. B. (1971). Simultaneous ipsilateral fracture of the femoral neck and shaft: report of 8 cases. South African Medical Journal, 45(4), 459467.

Malaspinas, A.-S., Westaway, M. C., Muller, C., Sousa, V. C., Lao, O., Alves, I., . . . Willerslev, E. (2016). A genomic history of Aboriginal Australia. Nature, 2016(538), 207. https://doi.org/10.1038/nature18299

Miller, G. H., Magee, J. W., Johnson, B. J., Fogel, M. L., Spooner, N. A., McCulloch, M. T., \& Ayliffe, L. K. (1999). Pleistocene Extinction of $<$ em $>$ Genyornis newtoni</em>: Human Impact on Australian Megafauna. Science, 283(5399), 205-208. https://doi.org/10.1126/science.283.539 9.205

Molan, P. C. (1999). The role of honey in the management of wounds. https://doi.org/10.12968/jowc.1999.8.8. 25904

Monroe, M. H. (2011). Australia: The Land Where Time Began. In. Australia: M. H. Monroe.

Mountford, C. P. (1981). Aboriginal conception beliefs: Hyland House Melbourne.

Net, C. (2016). Pace Calculator. Retrieved from http://www.calculator.net/pacecalculator $\cdot$ html?ctype $=$ pace $\&$ ctime $=00$ $\% 3 \mathrm{~A} 00 \% 3 \mathrm{~A} 10 \&$ cdistance $=100 \&$ cdista nceunit $=$ Meters $\&$ cpace $=00 \% 3 \mathrm{~A} 08 \% 3 \mathrm{~A}$ $10 \&$ cpaceunit $=$ tpm $\&$ printit $=0 \& \mathrm{x}=53 \& \mathrm{y}$ $=9$

Nigg, B. M., Cole, G. K., \& Nachbauer, W. (1993). Effects of arch height of the foot on angular motion of the lower extremities in running. Journal of biomechanics, 26(8), 909-916. 
https://doi.org/10.1016/0021-

9290(93)90053-H

Robert, B. (1878). The Aboriginies of

Victoria (Vol. 1).

Roberts, R. G., Flannery, T. F., Ayliffe, L. K., Yoshida, H., Olley, J. M., Prideaux, G. J., . . Smith, B. L. (2001). New

Ages for the Last Australian

Megafauna: Continent-Wide Extinction

About 46,000 Years Ago. Science, 292(5523), 1888-1892.

https://doi.org/10.1126/science.1060264

Rogers, H. (1966). The early history of the

Mornington Peninsula: Hallcraft

Publishing Company.

Rowley, K. G., Daniel, M., Skinner, K., Skinner, M., White, G. A., \& O'Dea, K. (2000). Effectiveness of a communitydirected 'healthy lifestyle' program in a remote Australian Aboriginal community. Australian and New NZeland Journal of Public Health, 24(2), 136-144.

https://doi.org/10.1111/j.1467-

842X.2000.tb00133.x

Scott, S., Duncan, C. J., \& Duncan, S. (1996). The plague in Penrith, Cumbria, 1597/8: its causes, biology and consequences. Annals of human biology, 23(1), 1-21. ttps://doi.org/10.1080/03014469600004 232

Shea, J. J. (2008). Transitions or turnovers? Climatically-forced extinctions of Homo sapiens and Neanderthals in the east Mediterranean Levant. Quaternary Science Reviews, 27(23), 2253-2270. https://doi.org/10.1016/j.quascirev.2008 .08 .015

Taçon, P. S. (1991). The power of stone: symbolic aspects of stone use and tool development in western Arnhem Land, Australia. Antiquity, 65(247), 192-207. https://doi.org/10.1017/S0003598X0007 9655
Taplin, W. J. G. (1879). The Native Tribes of South Australia. London: E. S. Wigg.

Tong, M. M., Altman, P. M., \& Barnetson, R. S. (1992). Tea tree oil in the treatment of tinea pedis. Australasian Journal of Dermatology, 33(3), 145149. https://doi.org/10.1111/j.14400960.1992.tb00103.x

Ulm, S. (2016, January 16). Map showing sea level changes over time. Retrieved from https://www .abc.net.au/news/2018-0116/map-showing-sea-level-changesover-time/9333538?nw=0

Vismer, H., Marasas, W., Rheeder, J., \& Joubert, J. (2002). Fusarium dimerum as a cause of human eye infections. Medical mycology, 40(4), 399-406. https://doi.org/10.1080/mmy.40.4.399.4 06

Voris, H. K. (2000). Maps of Pleistocene sea levels in Southeast Asia: shorelines, river systems and time durations. Journal of Biogeography, 27(5), 11531167. https://doi.org/10.1046/j.13652699.2000.00489.x

Watkins, C., Gale, M. A., Adelaide, S. I. o., \& School, K. P. (2006). Kaurna Alphabet Book: With an Introduction to the Kaurna Language: Kaurna Plains School.

Watson, P. (1983). This precious foliage: A study of the Aboriginal psycho-active drug pituri: University of Sydney.

Webb, S. (2007). Further research of the Willandra Lakes fossil footprint site, southeastern Australia. Journal of human evolution, 52(6), 711-715. https://doi.org/10.1016/j.jhevol.2007.02. 001

Webb, S., Cupper, M. L., \& Robins, R. (2006). Pleistocene human footprints from the Willandra Lakes, southeastern Australia. Journal of human evolution, 50(4), 405-413. 
https://doi.org/10.1016/j.jhevol.2005.10. 002

Westaway, M. (2010). Footprints of the First Australians. Australasian Science (2000), 31(2), 14.

Williams, A. N., Ulm, S., Cook, A. R., Langley, M. C., \& Collard, M. (2013). Human refugia in Australia during the Last Glacial Maximum and Terminal Pleistocene: a geospatial analysis of the 25-12 ka Australian archaeological record. Journal of Archaeological Science, 40(12), 4612-4625.

https://doi.org/10.1016/j.jas.2013.06.01 5

Wroe, S., \& Field, J. (2006). A review of the evidence for a human role in the extinction of Australian megafauna and an alternative interpretation. Quaternary Science Reviews, 25(21), 2692-2703. https://doi.org/10.1016/j.quascirev.2006 .03 .005 